\title{
Index of Authors
}

Numerals followed by the letter $A$ refer to pages in Abstracts of Communications read at Meetings for Original Communications of The Nutrition Society.

Acheson, E. D. Food policy, nutrition and government $13 \mathrm{I}-138$

Adron, J. W. see Bell, J. G. 42 A

Allen, K. G. D., Arthur, J. R., Davies, N. T., Morrice, P. C., Nicol, F. \& Mills, C. F. Copper deficiency and plasma glutathione concentration in rats $115 \mathrm{~A}$

Allison, Simon P. How I feed patients enterally $163-169$

ANIL, M. H., Jessop, N. \& Forbes, J. M. Control of liver enzyme activity by the autonomic nerves in sheep $77 \mathrm{~A}$

Animashaun, Aduke see Johnson, A. W. 68A

ARCHIBALD, R. F. see Watson, N. A. C. $98 A$

ARTHuR, J. R. see Allen, K. G. D. II 5 A

Arthur, J. R., Boyne, R., Morrice, P. C. \& Nicol, F. Selenium and neutrophil function in mice $6_{3} \mathrm{~A}$

Arthur, J. R., Bremner, I., Morrice, P. C. \& Mills, C. F. The inhibition of peroxidation in liver microsomes by glutathione but not by metallothionein 6IA

Aukett, A., Parks, Y. A., ScotT, P. H. \& WhARTON, B. A. Iron therapy increases the rate of weight gain and psychomotor development of anaemic toddlers: a double blind randomized controlled trial I23A

Backhouse, C. see Sian, M. S. $48 A$

BALkE, P.-O. see SNIDER, M. T. 64A

BARR, JULIE see HADDOCK, G. $22 \mathrm{~A}$

BASSETT, J. M. Nutrition of the conceptus: aspects of its regulation $\mathrm{I}-10$

Bates, P. C. see Coyer, Penny Io8A

Bates, P. C. see OMer, Asma B. II 4 A

Bates, P. C. see Yahya, Z. A. H. IOZA

Batstone, G. F., Helliwell, M., Coombes, E. J., Moody, B. J. \& Robertson, J. C. Nutritional status in rheumatoid arthritis $6 \mathrm{~A}$

Baust, Gul N. see Welchman, D. DE B. 32A

Beevers, D. G. Should recommendations be made to reduce dietary sodium intake? The case for recommendations $263-266$

Behrens, R., Northrop, C., Lunn, P., Neale, G. \& HANLON, P. Factors affecting the integrity of intestinal mucosa in Gambian children $67 \mathrm{~A}$

BELCH, J. J. F. see SHAPIRo, D. 3 IA

BELL, J. G., ADron, J. W. \& Cowey, C. B. The metabolism of $t$-butyl hydroperoxide and hydrogen peroxide by isolated perfused liver from control and selenium-deficient rainbow trout (Salmo gairdneri) $42 \mathrm{~A}$

Belton, N. R. see Grindulis, H. I22A

Bender, A. E. see Sandaradura, Sanoja S. I i $8 \mathrm{~A}$

Bender, David A. see Bior, Abdelaziz Deng 59A

Berrington, Janet see Johnson, A. W. 68A
Bior, Abdelaziz Deng \& Bender, David A. Aspartate aminotransferase $(E C$ 2.6.1.1) activation by pyridoxal phosphate as an index of vitamin $B_{6}$ nutritional status: validity in the presence of oestrogen conjugates $59 \mathrm{~A}$

BLACK, ALISON E. The use of recommended daily allowances to assess dietary adequacy $3^{69-38 I}$

Blackburn, N. A. see Edwards, C. A. $104 \mathrm{~A}$

BLAXTER, K. An historical perspective: the development of methods for assessing nutrient requirements $177-183$

Borzotta, A. P. see Clague, M. B. I7A

Boxer, Laurence A. Regulation of phagocyte function by $\alpha$-tocopherol $333-334$

BOYNE, R. see ARTHUR, J. R. 63 A

BrackenRIDGE, I. E. see Broom, J. $20 A$

BrAY, A. J. \& KeMM, J. R. Use of a computeradministered 'healthy eating' quiz for data collection and health promotion $86 \mathrm{~A}$

Bremner, I. see ARTHUR, J. R. 6i A

Brett, Aileen, Godden, D. J. \& Keenan, R. A. When and how should nutrition be taught to medical students? I 3

Breves, G., Gaebel, G., Martens, H. \& Hoeller, $H$. Phosphate fluxes across the rumen wall mucosa of sheep in vitro $99 \mathrm{~A}$

Broadhurst, A. J. \& Stockley, L. Calculation of fatty acid intake $45 \mathrm{~A}$

Brock, J. H. \& Mainou-Fowler, Tryfonia Iron and immunity $305-315$

Broom, J. see HepbURN, D. 33A

Broom, J., Brackenridge, I. E., Simpson, E., Miller, J. D. B. \& Morison, I. The effects of postoperative metabolic support on lipolytic rates in patients undergoing elective abdominal surgery $20 A$

Brown, D. see Noble, R. C. 56A

Brown, D. see Noble, R. C. IO3A

BroWNing, G. G. see WeIR, A. 74 A

Bryant, M. J. see Symonds, M. E. 93 A

Bull, A. P. see SNider, M. T. 64 A

Bulman, J. C., Naismith, D. J. \& Hillman, G. A nutritional evaluation of the tuber of the plant Cyperus rotundus $120 \mathrm{~A}$

Bunker, Valda see Lawson, Margaret $54 \mathrm{~A}$

Burgess, M. N. see McEwan, G. T. A. 80A

Burns, H. J. G. see Hansele, D. T. I4A

Burns, H. J. G. see Hansell, D. T. I 5 A

Burns, H. J. G. see Hansell, D. T. $28 \mathrm{~A}$

Buss, D. H. Variations in recommended nutrient intakes $345^{-35}$

Cain, C. J. see Cranwell, P. D. 8i A

Campbell, D. M. see Radcliffe, M. A. 73A

Campbell, I. T., Morton, R. P., Judd, S., Macdonald, I. A., Shapiro, L. \& Stell, P. M. The effects of continuous or nocturnal feeding on postoperative metabolism and catecholamine excretion $2 \mathrm{~A}$ 
Campbell-Brown, M., Johnstone, F. D. \& KerR Grieve, J. F. The effect on birth weight of a high-protein, low-carbohydrate diet during pregnancy $90 A$

CARr, K. see WeIR, A. 74A

Carter, D. C. see Hansel., D. T. 28A

Carter, Elaine Comparison of weight-for-height and arm circumference in the assessment of acute malnutrition I29A

Carver, N., van Persijn van Meerten, Els, Johnson, A. W. \& Sim, A. J. W. Normal anthropometric values for a large group of London subjects: comparison with surgical patients $5^{8 \mathrm{~A}}$

Chamberlain, D. G. see Girdler, C. P. $43 \mathrm{~A}$

Chan, S. T. F. see Johnson, A. W. 84 A

Chandler, K. D. see Cranwell, P. D. 8i A

Choo, J. J. \& Emery, P. W. The effect of an anabolic steroid (Durabolin) on body composition of rats fed on protein- and energy-restricted diets I09A

Clague, M. B., Borzotta, A. P. \& Johnston, Ivan D. A. Leucine and protein kinetics following surgery in man given varying branched-chain amino acid concentrations in a parenteral nutrition regimen $I 7 A$

Clapperton, J. L., Holt, C. \& Sweetsur, A. W. M. The effect of supplementary phosphate in the diet of lactating cows on the salt composition and heat stability of milk $46 \mathrm{~A}$

Clark, C. G. see Newham, D. J. I24A

Clark, I. A. see Stocker, R. $70 \mathrm{~A}$

Clark, R. G. see Quayle, A. R. 24A

Clayton, Barbara see Lawson, Margaret 54A

Close, W. H. see Lee, Pauline A. 89 A

Connor, K. see Dodds, P. F. 57A

CONNOR, K. see NOBLE, R. C. IOZA

COOKE, T. see SIAN, M. S. $48 A$

Coombes, E. J. see Batstone, G. F. 6A

Coubrough, Hazel \& McKinnon, Beryl, Some ways of improving the nutrition of patients who are receiving radiotherapy of the head or neck $2 \mathrm{IA}$

CoWEY, C. B. see BELL, J. G. $42 \mathrm{~A}$

Cox, M. see Coyer, Penny 53A

Coyer, Penny, Cox, M., Rivers, J. P. W. \& MILlWARD, D. J. Relation between increased heat production and 3,5, $3^{\prime}$-triiodothyronine concentration in rats treated with catabolic doses of corticosterone $53^{\mathrm{A}}$

Coyer, Penny, Donachie, P. A., Bates, P. C., Rivers, J. P. W. \& Millward, D. J. The effects of inhibiting corticosterone production with Trilostane on protein and energy metabolism in young rats given restricted amounts of dietary protein and energy 108A

Craigen, L. see Edwards, C. A. $104 \mathrm{~A}$

Cranwell, P. D., Chandler, K. D., Cain, C. J., McGillivery, D. J. \& Hennessy, D. P. Changes to the pars oesophagea in pigs before and after weaning on to a dry diet $8 \mathrm{IA}$

Cross, K. E. see Dodds, P. F. 57A

Crowe, S. see Stewart, J. T. IgA

Crump, Alison D. \& Rodway, R. G. Hypoglycae$\mathrm{mia}$ and luteinizing hormone release in the ewe rooA

Crump, B. J. see Situnayake, R. D. 66A

Crump, B. J. see Thurnham, D. I. $62 \mathrm{~A}$
Dalal, Shreedevi S. see Yahya, Z. A. H. I07A

Davies, J. A. see Situnayake, R. D. 66A

Davies, J. A. see Thurnham, D. I. 62A

Davies, J. W. L. see Hansell, D. T. I4A

Davies, J. W. L. see Hansell, D. T. I 5 A

Davies, J. W. L. see Hansell, D. T. $28 \mathrm{~A}$

Davies, N. T. see Allen, K. G. D. II A

Davis, M. see Situnayake, R. D. 66A

Davis, M. see Thurnham, D. I. 6zA

Davison, P. A. see Edwards, C. A. I04A

DE Benoist, B. see JaCkson, A. A. 92 A

de Caestecker, J. S., Shenkin, A., Fell, G. S. \& Heading, R. C. Hazards and benefits in a patient on long-term parenteral nutrition $23 \mathrm{~A}$

de la Hunt, M. see Griffin, C. $3^{\mathrm{A}}$

Dench, M. see Moghissi, K. I2A

Dickerson, J. W. T. see Qureshi, B. 6oA

Dickerson, J. W. T., Evans, Mair \& Holmes SUSAN Effects of radiotherapy on food acceptability in cancer patients $8 \mathrm{~A}$

Dickerson, J. W. T., Fekkes, J., Goodinson, S. M. \& Older, M. W. J. Postoperative food intake of elderly fracture patients $7 \mathrm{~A}$

D'Mello, J. P. F. see Harrison, Lydia $72 \mathrm{~A}$

Dodds, P. F. see Noble, R. C. $56 \mathrm{~A}$

Dodos, P. F., Cross, K. E., Noble, R. C. \& CoNNOR, K. Effects of diet on triacylglycerol levels in the liver, bile and serum and on the activities of enzymes concerned with lipid synthesis in the liver of the laying hen $57 \mathrm{~A}$

Dodson, P. M., Webberley, M. J. \& Waldron, S. P. Dietary sodium restriction in the treatment of mild hypertension $267-272$

Donachie, P. A. see Coyer, Penny Io8A

Donaldson, D. see QuREshi, B. 60A

Douglas, J. see KeMM, J. R. 87A

Downie, G., McRae, N. \& Will, I. G. Release of extractives from intravenous nutrition bags $29 \mathrm{~A}$

Draser, B. S. see RoY, S. $39 \mathrm{~A}$

DRUCE, E. Salt technology and dietary intake $253-257$

Drummond, Sandra \& Durnin, J. V. G. A. A simple exercise test for field use in studies of nutritional assessment $128 \mathrm{~A}$

Dudley, H. A. F. see Johnson, A. W. 84 A

Dudley, H. A. F. see Johnson, A. W. 125 A

DUERDEN, B. I. see TOMLIN, J. IO5A

Duggan, M. B. \& Milner, R. D. G. Measles, energy balance and childhood growth $35^{A}$

Durnin, J. V. G. A. see Drummond, Sandra I28A

EDE, D. A. Genetic control of skeletal development in the chick embryo $11-16$

Edwards, C. A. see Tomlin, J. 105 A

Edwards, C. A., Davison, P. A., Tomlin, J., Blackburn, N. A., Craigen, L., Sugden, K., Jarjis, H., Hessell, P. G., Park, C., LloydJones, J. G., Flockhart, I. R., Johnson, I. T. \& READ, N. W. The viscosity of viscous polysaccharides may change after ingestion $104 \mathrm{~A}$

EMERY, P. W. see ChOO, J. J. IOgA

Emery, P. W. see Woodward, C. J. H. 52A

Evans, Mair see Dickerson, J. W. T. 8A 
Fairweather-Tait, Susan J. \& Syms, Lisa L. The effect of extrusion cooking of maize on iron and zinc availability $4 \mathrm{IA}$

Fairweather-Tait, Susan J., Wright, A. J. A., Piper, Zoe \& LeUbA, J. L. The influence of human and bovine lactoferrin on iron absorption from ferrous sulphate in rats $4 \circ \mathrm{A}$

FeKkes, J, see Dickerson, J. W. T. 7 A

FeLl, G. S. see de CaEstecker, J. S. 23 A

Fell, G. S., Lyon, T. B., Phillitis, M. \& Fraser, W. Assessment of an in vitro serum protein $\mathrm{Zn}$-binding test in human nutrition $9 \mathrm{~A}$

Flockhart, I. R. see EdWards, C. A. IO4A

Forbes, J. M. see ANIL, M. H. 77 A

Francalancia, N. A. see Snider, M. T. 644

Fraser, W. see Fell, G. S. $9 A$

Gaebel, G. see Breves, G. $99 \mathrm{~A}$

Garden, O. J. see Weir, A. 74A

GaRdEN, O. J. see HaDDOCK, G. 22A

Garden, O. J. see Hansell, D. T. 28A

Garden, O. J. see Robertson, J. F. R. IOA

Garrow, J. S. see Lawson, SUSAN iz IA

Garrow, J. S. \& Webster, Joan D. Long-term results of treatment of severe obesity with jaw wiring and waist cord I I $9 A$

Gill, M. see Prates, E. R. 95 A

GiLL, M. see Sissons, J. W. $96 \mathrm{~A}$

GiLl, M. see Thiago, L. R. S. 97 A

GILL, $M$. Dynamic models: their use in understanding and predicting nutrient response $22 \mathrm{I}-229$

Girdler, C. P., Thomas, P. C. \& Chamberlain, D. G. Exogenous supply of glucose precursors and nitrogen utilization in sheep $43 \mathrm{~A}$

Gleeson, M., Maughan, R. J. \& Greenhaff, P. L. Effects of pre-exercise feeding of glycerol or glucose on metabolism and endurance performance in $\operatorname{man} 127 \mathrm{~A}$

Goode, A. see Johnson, A. W. $125^{A}$

Gooden, D. J. see Bret', AILEen I3A

Goodinson, S. M. see Dickerson, J. W. T. 7 A

Gore, M. see WaN, J. 27A

Greenhaff, P. L. see Gleeson, M. I27A

Greenhaff, P. L., McCormick, K. \& Maughan, R. J. The metabolic response to prolonged walking exercise in fed and fasted man $126 \mathrm{~A}$

Grennhalgh, J. F, D. Recent studies on the body composition of ruminants $119-13^{\circ}$

Greer, Anne, McBbride, I. M. \& Shenkin, A. Improvement in nutritional status of psychogeriatric patients on hospitalization $I I A$

Griffin, C., Royce, Catherine, de la Hunt, M. \& KARRAN, S. J. Lung cancer: a starving disease $3 \mathrm{~A}$

Griffiths, T. W. see Joseph, R. L. 63-69

Grimble, R. F. see Mohammed, A. I I 7 A

Grimble, R. F. see WAN, JENNIFER $38 \mathrm{~A}$

Grimble, R. F. see Wan, JenNifer 5iA

Grimble, R. F. see Wan, JenNifer $83 \mathrm{~A}$

Grimble, R. F. see Wan, Jennifer i i $3 A$

Grimble, R. F. see WaN, J. 27A
Grindulis, H., ScotT, P. H., Belton, N. R. \& Wharton, B. A. An association of anaemia with poor vitamin $D$ status in otherwise adequately nourished Asian toddlers: a case for combined prophylaxis $122 \mathrm{~A}$

Haddock, G., Barr, Julie, Ross, Aileen \& GARDEN, O. J. Experience of a nutrition group in the reduction of complications of central venous catheters 22A

Halliday, D. see Ward, H. C. I6A

Hanlon, P. see Behrens, R. 67A

Hannah, M. J. see Symonds, M. E. $79 A$

Hansell D. T., Davies, J. W. L. \& Burns, H. J. G. Some long-term metabolic effects of primary tumour removal in patients with or without metastases $14 \mathrm{~A}$

Hansele, D. T., Davies, J. W. L., Burns, H. J. G., Garden, O. J., Shenkin, A. \& Carter, D. C. A clinical evaluation of a new, effective peripherallyadministered parenteral nutrition regimen $28 \mathrm{~A}$

Hanseli, D. T., Davies, J. W. L., Shenkin, A. \& Burns, H. J. G. Substrate oxidation in weightstable and weight-losing cancer patients ${ }_{5} \mathrm{~A}$

Harrison, Lydia \& D'Mello, J.P. F. Large neutral amino acids in the diet and neurotransmitter concentrations in the chick brain $72 \mathrm{~A}$

Hay, S. C. see RadCliffE, M. A. 73 A

Heading, R. C. see de Caestecker, J. S. 23A

Heatley, J. V. see Johnson, A. W. 68A

Heatley, R. V. see Rathbone, B. J. 6gA

Helliwell, M. see Batstone, G. F. 6A

Henderson, I. S. see McKenzie, Sheila 25A

Hennessy, D. P. see Cranwell, P. D. 8I A

Henning, Susan J. Development of the gastrointestinal tract $39-44$

Hepburn, D., Broom, J. \& Smith, D. J. A study of the time course of fructose-2,6-bisphosphate production in a septic mouse model $33 \mathrm{~A}$

Heppell, L. M. J. see Low, A. G. 55 A

Hessel., P. G. see Edwards, C. A. $10_{4} A$

Hill, R. see SMITH, I. M. 34A

Hillman, G. see Bulman, J. C. IzoA

Hoeller, H. see Breves, G. 99A

Holder, A. T. see YahyA, Z. A. H. Io7A

Holmes, Susan see Dickerson, J. W. T. 8A

Holt, C. see Clapperton, J. L. 46A

Hunt, N. H. see Stocker, R. $70 A$

Jackson, A. A., Persaud, C., McDermott, J. \& de Benorst, B. Glycine insufficiency in pregnancy assessed by urinary pyroglutamic acid excretion $92 \mathrm{~A}$

JaRJIS, H. see EDWARDS, C. A. I04A

Jepson, M. M., Pell, J. M. \& Millward, D. J. Effect of inhibition of corticosterone production by Trilostane on the catabolic response of the rat to the Escherichia coli endotoxin $50 \mathrm{~A}$

Jepson, M., Pell, J. M. \& Millward, D. J. The effect of fasting on the acute response of protein synthesis in muscle and liver to the Escherichia coli lipopolysaccharide $36 \mathrm{~A}$

Jessop, N. see ANIL, M. H. 77 A

JEWITT, T. R. see MACLEOD, M. G. 75 A 
Johnson, A. W. see Carver, N. $5^{8 A}$

Johnson, A. W. see Rathbone, B. J. 69 A

Johnson, A. W. see Singh, S. 85A

Johnson, A. W., Animashaun, Aduke, Berrington, Janet, Heatley, R. V. \& Losowsky, M. S. Amino acid requirements in acute disease $68 \mathrm{~A}$

Johnson, A. W., Chan, S. T. F., Kapadia, C. R. \& Dudley, H. A. F. The interrelation between glycogen, water and potassium $\mathbf{8 4} \mathrm{A}$

Johnson, A. W., Radchiffe, A. G., Goode, A. \& Dudley, H. A. F. The use of transferrin and ferritin as 'nutritional' indices $125 \mathrm{~A}$

JoHnson, I. T. see EDWARDS, C. A. 104A

Johnson, I. T. see SWindelt, T. E. 37A

Johnston, Ivan D. A. see Clague, M. B. i 7 A

Johnstone, F. D. see CAMpbell-Brown, M. 90A

Jones, Christine see Rathbone, B. J. $69 A$

Jones, D. G see SUTtLE, N. F. 317-325

JoNEs, R. L. Nutritional influences on carcass composition in the broiler chicken $27-32$

Joseph, R. L. \& Griffiths, T. W. Animal meat products, processing and the consumer $63-69$

JudD, S. see CAMPBElL, I. T. 2 A

Kapadia, C. R. see Johnson, A. W. 84 A

Karran, S. J. see Griffin, C. $3^{A}$

Karran, S. J. see Royce, Catherine 4 A

KEENAN, R. A. see BRETT, AILEEN I3A

Kelleher, J. see RATHBone, B. J. 69A

KEMM, J. R. see BRAY, A. J. 86A

Kemm, J. R., Douglas, J. \& Sylvester, V. A survey of infant feeding practice by Afro-Caribbean mothers in Birmingham $87 \mathrm{~A}$

Kempster, A. J. Correlations between indirect and direct measurements of body composition $55^{-52}$

Kerr Grieve, J. F. see Camprell-Brown, M. $90 A$

Kilgour, E. \& Vernon, R. G. Activation of pyruvate dehydrogenase in rat white adipose tissue by both insulin and noradrenaline is muted during lactation $76 \mathrm{~A}$

Kirkman, Rachel J. see Symonds, M. E. $79 A$

Lawson, Margaret, Bunker, Valda \& Clayton, Barbara Gut transit time measured by three markers 54A

Lawson, Susan, Webster, Joan D., Pacy, P. J. \& Garrow, J. S. Effect of a to week jogging programme on metabolic rate in lean sedentary females I $21 A$

LEAN, A. P. see Rose, S. P. IO2A

Lee, Pauline A. \& Close, W. H. The effects of energy intake in pregnancy and lactation on the reproductive performance of the sow and growth of the litter $89 \mathrm{~A}$

LEIPER, J. B. Absorption of water and electrolytes from hypotonic, isotonic and hypertonic solutions $78 \mathrm{~A}$

Leuba, J. L. see Fairweather-Tait, Susan J. 4 OA

LEVER, A. F. Should recommendations be made to reduce dietary sodium intake? The case against recommendations 259-262

LINDSAY, D. B. \& ODDY, V. H. Development of the neonatal lamb and piglet $33-38$

Lloyd-Jones, J. G. see Edwards, C. A. 104 A
Loblex, G. E. The physiological bases of nutrient responses; growth and fattening 203-214

Lomax, M. A. see Symonds, M. E. 79 A

Lomax, M. A. see Symonds, M. E. 93A

Losowsky, M. S. see Johnson, A. W. 68A

Losowsky, M. S. see Singh, S. $8{ }_{5}$ A

Low, A. G., Zebrowska, Teresa, Heppell, L. M. J. \& Sмiтн, H. A. Influence of wheat bran, cellulose, pectin and low or high viscosity guar gum on glucose and water absorption from pig jejunum $55^{A}$

LucAs, M. L. see McEwan, G. T. A. 80A

LUNN, P. see BEHRENS, R. 67A

Lyon, T. B. see FELL, G. S. 9 A

McBride, D. M. see Greer, Anne i i A

MCCARTNEy, R. see Noble, R. C. 56A

MCCONKEY, B. see SitunaYAKE, R. D. 66A

MCCORMick, K. see GREenhafF, P. L. I26A

MCCracken, K. J. Nutritional obesity and body composition $9 \mathrm{I}-\mathrm{IOO}$

McDermott, J. see Jackson, A. A. 92A

Macdonald, I. A. see Campbell, I. T. $2 A$

McDonald, I. see Robinson, J. J. gi A

McEwan, G. T. A., Burgess, M. N. \& Lucas, M. L. Effect of Escherichia coli enterotoxin (STa) on mucosal surface $\mathrm{pH}$ in vivo in rat proximal jejunum $80 A$

McGillivery, D. J. see Cranwell, P. D. 8iA

MCKenzie, Sheila I. \& Henderson, I. S. The effect of increased dietary fibre intake in patients with chronic renal failure $25 \mathrm{~A}$

McKinnon, Beryl see Coubrough, Hazel 2 i A

MacLeod, M. G. \& JewitT, T. R. Heat production and physical activity in laying hens on an intermittent-lighting regime $75^{\mathrm{A}}$

McMahon, M. J. Why I feed patients with trauma and sepsis $139^{-1} 5^{1}$

McRae, N. see Downie, G. 29A

MaIn, J. see StewaRT, J. T. IgA

Main, J., Stewart, J. T. \& Pennington, C. R. Parenteral nutrition: a review of complications I $8 \mathrm{~A}$

Mainou-Fowler, Tryfonia see Brock, J. H.

305-315

Mangnall, D. see Quayle, A. R. 24 A

Manns, J. G. see RutTer, L. M. $88 A$

Martens, H. see Breves, G. $99 \mathrm{~A}$

Mathieson, N. see Rose, S. J. 26A

Maughan, R. J. see Gleeson, M. 127A

Maughan, R. J. see Greenhaff, P. L. I26A

Mercer, S. W. \& Williamson, D. H. The influence of carbohydrate availability on the regulation of lipogenesis in the lactating mammary gland of the rat I $16 \mathrm{~A}$

Miller, J. D. B. see Broom, J. $20 A$

Milligan, L. P. \& Summers, M. The biological basis of maintenance and its relevance to assessing responses to nutrients $185-193$

Mills, C. F. see Allen, K. G. D. 1 I 5 A

Mills, C. F. see Arthur, J. R. 6i A

Millward, D. J. see Coyer, Penny 53A

Millward, D. J. see Coyer, Penny IO8A

Millward, D. J. see OMER, ASma, B. II4A 
Millward, D. J. see Yahya, Z. A. H. Io7A

Millward, D. J. see Jepson, M. M. $5 \circ \mathrm{A}$

Millward, D. J. see Jepson, M. 36A

MilneR, R. D. G. see DugGan, M. B. 35 A

MoE, P. W. \& Tyrrell, H. F. The physiological bases of nutrient responses during lactation 21 5-220

Moghissi, K., Dench, M. \& Pearson, J. Value of preoperative parenteral feeding in patients with cancer of the oesophagus undergoing major surgery $12 \mathrm{~A}$

Mohammed, A., Grimble, R. F., Taylor, T. G. \& RATClifFe, B. A study of the possible role of the intestinal microflora in phytate hydrolysis in chicks II $7 \mathrm{~A}$

Moody, B. J. see Batstone, G. F. 6A

MoRAN, E. T. Variations in body composition of poultry IOI- IO9

Morell, D. see Yahya, Z. A. H. IO7A

Morgan, Jane B. see Qureshi, B. 6oA

Morison, I. see Broom, J. 20A

Morrice, P. C. see Allen, K. G. D. I I 5 A

Morrice, P. C. see ArthuR, J. R. 6iA

Morrice, P. C. see Arthur, J. R. 63A

Morton, R. P. see CAMPBELL, I. T. $2 A$

Mulley, G. P. see Singh, S. $8{ }_{5} A$

Naismith, D. J. see Bulman, J. C. I2OA

NEALE, G. see BeHRENS, R. 67A

Newham, D. J., Tomkins, A. M. \& Clark, C. G. The effect of hypoenergetic feeding for 2 weeks on the contractile properties of the adductor pollicis of obese patients $124 \mathrm{~A}$

Nicol, F. see Allen, K. G. D. II 5 A

Nicol, F. see ARThur, J. R. 63A

Noble, R. C. see Dodds, P. F. $57 \mathrm{~A}$

NoBle, R. C. Lipid metabolism in the chick embryo 1 7-25

Noble, R. C., McCartney, R., Brown, D. \& Donds, P. F. Comparative changes in the lipid compositions of liver and bile of the female broiler bird $5^{6} \mathrm{~A}$

Noble, R. C., Shand, J. H., Connor, K. \& Brown, D. Effects of parental age on fatty acid oxidation in vitro by the liver and heart of the chick embryo $\mathrm{IO}_{3} \mathrm{~A}$

Northrop, C. see Behrens, R. $67 \mathrm{~A}$

OddY, V. H. see LINDSAY, D. B. $33^{-3} 8$

Oerter, K. E. see SNIDER, M. T. 64A

Older, M. W. J. see Dickerson, J. W. T. $7^{A}$

Omer, Asma B., Bates, P. C. \& Millward, D. J. Response of the vitamin-E-deficient rat to severe protein deficiency and the Escherichia coli endotoxin $I_{4} \mathrm{~A}$

Pacy, P. J. see Lawson, Susan izia

Park, C. see Edwards, C. A. IO4A

Parks, Y. A. see Aukett, A. I23A

Pasko, K. A. see Snider, M. T. 64A

Pearson, J. see Moghissi, K. izA

Pearson, R. Anne see Watson, N. A. C. $98 A$

Pell, J. M. see Jepson, M. M. 5OA

Pel.l, J. M. see Jepson, M. 36A
Pennie, I. see Robinson, J. J. gi A

Pennington, C. R. see Main, J. i8A

Pennington, C. R. see Stewart, J. T. igA

Persaud, C. see Jackson, A. A. 92 A

Pettigrew, R. A. Preoperative nutrition: a simple classification for the selection of patients and its relation to clinical assessment $5 \mathbf{A}$

Philipps, N. J. \& Pond, C. M. Adipose tissue cellularity and site-specific differences in adipocyte volume in genetically obese $(o b / a b)$ mice Ior A

Phillips, M. see Fell, G. S. 9A

Piper, Zoe see Fairweather-Tait, Susan J, $40 A$

POND, C. M. see Philipps, N. J. IOIA

Powers, Hilary J. Maternofetal iron transfer in the riboflavin-deficient rat $94 \mathrm{~A}$

Prates, E. R., Thiago, L. R. S., Gill, M. \& Theodorou, M. K. The effect of conservation method and frequency on rumen microbial activity $95 \mathrm{~A}$

Quayle, A. R., Mangnall, D. \& Clark, R. G. Parenteral nutrition in the management of short-bowel syndrome $24 \mathrm{~A}$

Qureshi, B., Sheikh, Farah, Donaldson, D., Morgan, Jane B. \& Dickerson, J. W. T. Birth weight and feeding practices of infants in Southall, Middlesex $60 \mathrm{~A}$

Radcliffe, A. G. see Johnson, A. W. 125 A

Radcliffe, M. A., HaY, S. C. \& Camphell, D. M. Effect of litter size on parametrial white fat cell size and lipolysis in lactating rats $73 \mathrm{~A}$

Ratcliffe, B. see Mohammed, A. I $17 \mathrm{~A}$

Rathbone, B. J., Johnson, A. W., Jones, Christine, Kelleher, J. \& Heatley, R. V. Gastric juice 'secretion' of ascorbic acid $69 \mathrm{~A}$

READ, N. W. see EDWARDS, C. A. IO4A

READ, N. W. see Tomlin, J. IO5A

Richards, J. see Stewart, J. T. IgA

Richardson, R. A. see WeIr, A. $74 \mathrm{~A}$

Rivers, J. P. W. see Coyer, Penny 53A

Rivers, J. P. W. see Coyer, Penny io8A

Robbins, M. E. see SNider, M. T. 64A

Robertson, J. C. see Batstone, G. F. 6A

Robertson, J. F. R., Garden, O. J. \& Shenkin A. Intravenous nutrition and hepatic dysfunction: a retrospective study $\mathrm{I} \circ \mathrm{A}$

RoBinson, J. J. Changes in body composition during pregnancy and lactation $7 \mathrm{I}-80$

Robinson, J. J., McDonald, I., Pennie, K. \& SMART, R. I. The body composition of nutritionally-restricted ovine fetuses compared with young fetuses of the same weight 9 IA

Robinson, S. M. \& YoRK, D. A. Thermic responses to a standard meal in matched smoking and non-smoking female subjects I IOA

Rodway, R. G. see Crump, Alison D. $100 \mathrm{~A}$

Rose, S. J., White, A. \& Mathieson, N. A method for indirect study of neonatal gut flora? $26 \mathrm{~A}$

Rose, S. P. \& LEAN, A. P. Fatness of laying hens and their response to reduced energy intakes $102 \mathrm{~A}$

Ross, Aileen see Haddock, G. 22A

Rothwell, Nancy J. \& Stock, Michael J. Chronic effects of Baclofen on energy balance and thermogenesis in the rat $112 \mathrm{~A}$ 
Rothwell, Nancy J. \& Stock, Michael J. Possible involvement of prostaglandins in dietinduced thermogenesis of 'cafeteria' fed rats i i I A

Roy, S., Draser, B. S. Tomkins, A. M. The impact of zinc deficiency on the intestinal response to cholera toxin $39 \mathrm{~A}$

Royce, Catherine see Griffin, C. 3 A

Royce, Catherine, Sutton, G. L. \& Karran, S. J. Can postoperative peripheral feeding reduce. complications following major surgery? $4 \mathrm{~A}$

RutTer, L. M. \& MANNS, J. G. Acute hypoglycaemia inhibits increased luteinizing hormone pulsatility associated with weaning in postpartum beef cows $88 \mathrm{~A}$

Sandaradura, Sanoja S. \& Bender, A. E. Effect of oral chlortetracycline on faecal DNA excretion and mucosal cell turnover in rats fed on legumes $118 \mathrm{~A}$

SchriJver, J. see van der BEEK, E. J. $6_{5} A$

Scott, P. H. see AuketT, A. 123A

ScotT, P. H. see Grindulis, H. 122A

Shand, J. H. see NoBle, R. C. $\operatorname{IO}_{3} \mathrm{~A}$

Shapiro, D., Belch, J. J. F., Sturrock, R. D. \& ShENkin, A. Effects of drugs altering arachidonic acid metabolism on production of interleukin $I$ by monocyte-like cells 3 I A

Shapiro, L. see Campbell, I. T. $2 A$

SheIKH, Farah see QuREshi, B. 6oA

Shenkin, A. see de Caestecker, J. S. 23A

Shenkin, A. see Greer, ANne it A

Shenkin, A. see Hansell, D. T. I5A

Shenkin, A. see Hansell, D. T. $28 \mathrm{~A}$

Shenkin, A. see Robertson, J. F. R. IOA

Shenkin, A. see Shapiro, D. 3 IA

Shenkin, A. see Weir, A. $74 A$

SHENKIN, A. Vitamin and essential trace element recommendations during intravenous nutrition: theory and practice $383-390$

Shepherd, D. A. L. see Symonds, M. E. 93 A

SHEPHERD, R. \& STOCKLEY, L. The role of attitudes and nutritional knowledge in fat consumption $44 \mathrm{~A}$

Sian, M. S., Backhouse, C. \& Cooke, T. Faecal bile acid profiles and colonic carcinogenesis $48 \mathrm{~A}$

Silk, D. B. A. When I feed medical patients $153^{-16}$ I

Sim, A. J. W. How I feed patients intravenously $171-176$

Sim, A. J. W. see Carver, N. $58 \mathrm{~A}$

SIM, A. J. W. see WARD, H. C. I6A

Simpson, E. see Broom, J. $20 A$

Singh, S., Johnson, A. W., Mulley, G. P. \& Losowsky, M. S. Undernutrition in Alzheimer's disease $85 \mathrm{~A}$

Sissons, J. W., Gill, M. \& Thiago, L. R. S. Effect of conservation method and frequency of feeding on forestomach motility $96 \mathrm{~A}$

SitunaYake, R. D. see ThURnhaM, D. I. 6zA

Situnayake, R. D., ThurnhaM, D. I., Davies, J. A., Crump, B. J., Davis, M. \& McConkey, B. Examination of nutritional factors in rheumatoid arthritis: relation with markers of lipid peroxidation $66 \mathrm{~A}$

SMART, R. I. see RoRINSON, J. J. grA

SMith, D. J. see HepbuRN, D. $33^{A}$
Sмгтн, H. A. see Low, A. G. 55 A

Smith, I. M. \& HıLL, R. Further observations on the effects of supplements of iron on growing fowl inoculated with Salmonella gallinarum $34 \mathrm{~A}$

SNider, M. T., Balke, P.-O., Oerter, K. E., Francalancia, N. A., Bull, A. P., Pasko, K. A. \& Robbins, M. E. Lipid peroxidation during muscular exercise in man: inferences from the pulmonary excretion of $n$-pentane, isopentane and nitrogen 64A

Stell, P. M. see Campbell, I. T. 2 A

Stewart, J. T. see MaIn, J. I8A

Stewart, J. T., Pennington, C. R., Main, J., Crowe, S. \& Richards, J. Home parenteral nutrition: a cost-effective evaluation $I g A$

Stock, Michael J. see Rothwell, Nancy J. II IA Stock, Michael, J. see Rothwell, Nancy J. I I 2 A Stocker, R., Hunt, N. H., Weidemann, M. J. \& Clark, I. A. Changes in the endogenous anti-oxidant levels of plasma and erythrocytes during Plasmodium vinckei malaria $70 \mathrm{~A}$

STOCKLEY, L. see BroAdHURST, A. J. $45 A$

Stockley, L. see SHePHeRd, R. 44 A

Sturrock, R. D. see SHAPIRo, D. 3 IA

Sugden, K. see EDWARds, C. A. ro4A

Summers, M. see Milligan, L. P. 185-193

Suttle, N. F. \& Jones, D. G. Copper and disease resistance in sheep: a rare natural confirmation of interaction between a specific nutrient and infection 3 1 7-325

Sutton, G. L. see Royce, Catherine 4 A

Sweetsur, A. W. M. see Clapperton, J. L. 46 A

SWINDELL, T. E. \& Johnson, I. T. The effect of guar gum on the mucosal regulation of iron absorption in rats $37 \mathrm{~A}$

SYLVESTER, V. see KEMM, J. R. 87 A

Symonds, M. E., BRYANT, M. J., Shepherd, D. A. L. \& LomAX, M. A. Glucose metabolism in shorn and unshorn pregnant sheep $93 \mathrm{~A}$

Symonds, M. E., Hannah, M. J., Kirkman, Rachel J. \& Lomax, M. A. The effect of intravenous infusion of noradrenaline on lipolysis in adult sheep $79 \mathrm{~A}$

Syms, Lisa L. see FaIRweather-TatT, Susan J. $41 \mathrm{~A}$

Tadesse, K. \& Wong, BetTy Is it time to change the standard lactose tolerance test? $47 \mathrm{~A}$

Taylor, A. see Yahya, Z. A. H. IO7A

Taylor, T. G. see Mohammed, A. I 7 A

Theodorou, M. K. see Prates, E. R. 95A

Thiago, L. R. S. see Prates, E. R. $95 A$

Thiago, L. R. S. see Sissons, J. W. $96 \mathrm{~A}$

Thiago, L. R. S. \& GiLL, M. The effect of conservation method and frequency of feeding on the removal of digesta from the rumen $97 \mathrm{~A}$

Thomas, P. C. see Girdler, C. P. 43 A

Thurnham, D. I. see Situnayake, R. D. 66A

Thurnham, D. I., Crump, B. J., Davies, J. A., SITUNAYAKE, R. D. \& Davis, M. Nutritional status of vitamins $E, C$ and $B_{2}$ in alcoholics in relation to the plasma phospholipid-2-esterified 9, I I-linoleic acid:9, 12-linoleic acid value $62 \mathrm{~A}$

Tomkins, A. M. see NewhaM, D. J. I24A 
Tomkins, A. M. see Roy, S. 39 A

ToMkINS, ANDREw M. Protein-energy malnutrition and risk of infection $289-304$

Tomlin, J. see Edwards, C. A. ${ }^{104}$ A

Tomlin, J., Edwards, C. A., Duerden, B. I. \& READ, N. W. Degradation of guar gum by faecal bacteria $105 \mathrm{~A}$

TUCKer, M. A. M. see UTERMOHLEN, V. 327-33I

Tyrrell, H. F. see MoE, P. W. 215-220

Utermohlen, V. \& Tucker, M. A. M. Possible effects of dietary $n-6$ series polyunsaturated fatty acids on the development of immune dysfunction and infection $327-331$

vaN Der Beek, E. J., van Dokkum, W., Schrijver, J. \& WEDEL, M. Vitamin C restriction and physical performance $65 \mathrm{~A}$

VAN DOKKUM, W. see VAN DER BeEK, E. J. 65A

van Persijn van Meerten, Els see Carver, N. $58 \mathrm{~A}$

VERNON, R. G. see KILGOUR, E. $76 \mathrm{~A}$

Waldron, S. P. see Dodson, P. M. 267-272

WALKER, D. M. Body composition of animals during sucking and the immediate post-weaning period $8 \mathrm{I}-89$

Wan, J., Grimble, R. F. \& Gore, M. Effects of dietary fat concentration and saturation on the catabolic response of protein metabolism to Escherichia coli endotoxin $27 \mathrm{~A}$

WAN, JenNifer \& Grimble, R. F. Diurnal influences on the metabolic effects of two types of Escherichia coli endotoxin in rats $8_{3} \mathrm{~A}$

Wan, Jennifer \& Grimble, R. F. Effect of a lipoxygenase inhibitor, AA86r, on the metabolic response to Escherichia coli endotoxin in rats $3^{8 \mathrm{~A}}$

Wan, Jennifer \& Grimgle, R. F. Effects of Propranolol on fever, hypothermia and other metabolic effects of Escherichia coli endotoxins II $A$

WAN, JeNNifer \& Grimble, R. F. Inhibitory effects of indomethacin on some features of the metabolic response to Escherichia coli endotoxin in rats $5 \mathrm{IA}$

Ward, H. C., Halliday, D. \& Sim, A. J. W. Whole-body protein synthesis and energy balance in surgical patients $16 \mathrm{~A}$
Waterlow, J. C. Notes on the new international estimates of energy requirements $35 \mathrm{I}-360$

Watson, N. A. C., Pearson, R. Anne \& ARChibaLd, R. F. Effect of ambient temperature and urea supplementation on the intake of fibrous diets by draught ruminants $98 \mathrm{~A}$

WEBberLey, M. J. see DoDSON, P. M. 267-272

Webster, A. J. F. Factors affecting the body composition of growing and adult animals $45-53$

Webster, JoAN D. see GaRrow, J. S. IIgA

Webster, Joan D. see Lawson, Susan izia

WEDEL, M. see vaN DER BEEK, E. J. 65A

WEEKs, T. E. C. Key hormonal and metabolic control systems modifying nutrient use $195^{-202}$

WeidemanN, M. J. see Stocker, R. 70A

Weir, A., Richardson, R. A., Carr, K., Shenkin, A., Garden, O. J. \& Browning, G. G. A comparison of continuous and intermittent postoperative nasogastric nutrition after major head and neck surgery $74 \mathrm{~A}$

Welchman, D. DE B. \& Baust, Gul N. Associations between feeding, housing and the incidence of abomasal ulcers in veal calves $32 \mathrm{~A}$

Wharton, B. A. see AuketT, A. $123 \mathrm{~A}$

Wharton, B. A. see Grindulis, H. 122A

WhITE, A. see Rose, S. J. 26A

Whitehead, R. G. Principles involved in assessing energy, protein and micronutrient needs during infancy $36 r-367$

Whittemore, Colin T. Causes of variation in the body composition of growing pigs $I I I-I I 7$

WILL, I. G. see DownIE, G. $29 \AA$

Williamson, D. H. see MERCER, S. W. II6A

WONG, BETTY see TADESSE, K. 47A

Woodward, C. J. H. \& EMERY, P. W. Energy balance of corticosterone-treated rats in relation to body composition $52 \mathrm{~A}$

Wright, A. J. A. see Fairweather-Tait, Susan J. $40 \mathrm{~A}$

Yahya, Z. A. H., Bates, P. C., Dalal, Shreedevi S., Morell, D., Holder, A. T., Taylor, A. \& Millward, D. J. The effect of dietary protein concentration on bone and muscle growth and immunoreactive somatomedin $\mathrm{C}$ in the rat $107 \mathrm{~A}$

YoRk, D. A. see Robinson, S. M. IIOA

Zebrowska, Teresa see Low, A. G. 55 A 